\title{
Analisis kerentanan penduduk Desa Pulungdowo terhadap Covid-19
}

\author{
Purwanto*, Krisma Sari, Maylinda Maghfiroh, Mira Ayu Pratiwi, Muchammad Ryan \\ Pratama, Muhammad Ikmal, Musnizar Zulaiha Umami, Novy Aulia Istighfary, Raka \\ Erditama Nurahman, Rizky Fitra Sanjaya, Zahrina Fatmala \\ Universitas Negeri Malang, Jl. Semarang No. 5 Malang, Jawa Timur, Indonesia \\ *Penulis korespondensi, Surel: purwanto.fis@um.ac.id
}

Paper received: 01-04-2021; revised: 15-04-2021; accepted: 30-04-2021

\begin{abstract}
Abstrak
Penelitian ini bertujuan menganalisis rasio kerentanan masyarakat terhadap kesadaran dalam menggunakan alat pelindung diri pada kasus Covid-19 di Jawa Timur. Penelitian ini menggunakan perspektif spasial sebagai dasar melakukan analisis. Data dikumpulkan melalui survey, wawancara, dan data sekunder dari web resmi pemerintah. Survei kesadaran masyarakat dilakukan dengan menggunakan survey 123 dari ESRI yang meliputi wilayah Malang raya dan Jawa Timur. Survey dilakukan di 197 titik di wilayah jawa Timur. Rasio kerentanan diperoleh dengan membandingkan rasio jumlah penduduk usia lanjut dengan jumlah penduduk total menurut kementerian dalam negeri Indonesia. Untuk melihat lebih dalam rasio kerentanan dilihat berdasarkan jenis gender. Hasil penelitian menunjukkan rasio kerentanan desa Pulungdowo dalam kategori sedang dengan skor 0.1875, dengan menempatkan rasio kerentanan perempuan lebih tinggi dari pada laki-laki. Berdasarkan hasil tersebut perempuan memiliki tingkat kesadaran spasial lebih tinggi daripada lakilaki.
\end{abstract}

Kata kunci: kerentanan penduduk; Covid-19; kesadaran spasial masyarakat

\section{Pendahuluan}

Coronavirus Disease 2019 atau yang lebih sering dikenal dengan Covid-19 merupakan sebuah wabah penyakit menular yang disebabkan virus pada hewan dan menular cepat pada manusia (Contini et al., 2020). Covid-19 muncul sebagai sebuah penyakit baru dan menjadi sebuah ancaman kesehatan besar di setiap negara, terutama negara dengan jumlah penduduk yang sangat besar. Munculnya Covid-19 berasal dari Wuhan, China pada Desember 2019 dengan nama Severe Acute Respiratory Syndrome Coronavirus 2 (SARS- COV2) (Bhattacharya et al., 2020). Menurut sebuah studi, selain menyerang sistem pernapasan pada manusia para peneliti di Shanghai dan New York melaporkan bahwa Covid-19 juga dapat menyerang imunitas atau sistem kekebalan manusia dan menyebabkan kerusakan yang serupa dengan pasien pengidap HIV (Yuliana, 2020).

Penyebaran Covid-19 ke seluruh dunia sangatlah cepat hal itu disebabkan telah berpindahnya system penularan dari manusia ke manusia (Shereen et al., 2020). Minimnya penanganan dan pengalaman karena belum diketahuinya pola dan cara virus bekerja serta belum ditemukannya vaksin. Salah satu upaya meminimalisasi dampak tersebut adalah dengan memutus mata rantai melalui berbagai tindakan dan kebijakan. Lockdown, social distancing, Pembatasan Sosial Berskala Besar (PSBB), Pembatasan Sosial Berskala Lokal (PSBL), isolasi diri dan penggunaan alat pelindung diri serta memberikan sanksi hukum bagi pelanggar protocol Kesehatan, semua itu adalah bentuk kebijakan dan Tindakan untuk 
meminimalisir penyebaran Covid-19. Namun, sejauh mana kebijakan tersebut efektif hasilnya belum jelas (Lau et al., 2020), sebagaimana fakta saat ini jumlah kasus positif terus meningkat.

Menurut beberapa pakar bahwa kebijakan lockdown dapat mengurangi resiko penyebaran infeksi dan kematian akibat COVID-19. Sebagaimana di Inggris, Lockdown mampu menurunkan 25\% seminggu setelah diberlakukan kebijakan (Thornton, 2020). Namun, muncul beberapa permasalahan dalam lingkup sosio-ekonomi, meliputi diskriminasi dan kekerasan gender meningkat pesat; sektor bisnis formal dan informal, ekonomi, dan pendidikan terhambat; hilangnya mata pencaharian dan meningkatnya jumlah pengangguran yang menyebabkan penderitaan, khususnya masyarakat golongan miskin di perkotaan maupun pedesaan (Shammi et al., 2020). Terjadi oversleeping yang mengakibatkan gangguan kesehatan fisik dan mental seperti depresi ringan (mood rendah) selama lockdown diterapkan (Majumdar et al., 2020).

COVID-19 dapat menular dalam berbagai media baik melalui kontak langsung maupun tidak langsung. Penularan secara langsung jika terjadi kontak langsung dengan penderita. Penularan dapat terjadi melalui batuk, bersin, maupun percikan yang keluar dari mulut dan hidung orang yang terinfeksi. Percikan tersebut kemudian juga dapat menempel pada bendabenda yang sering disentuh manusia oleh sebab itu penyebaran virus ini menjadi sangat cepat (WHO, 2020). Demikian halnya orang yang sehat sekalipun dapat menjadi perantara penyebaran virus ini (Dowd et al., 2020; Leung, 2020).

Meningkatnya kasus positif diberbagai negara menyebabkan kekhawatiran masyarakat secara global (Lau et al., 2020), termasuk WHO (World Health Organization) sebagai organisasi kesehatan dunia. Indonesia adalah salah satu negara di Asia Tenggara yang memiliki resiko tinggi terhadap penyebaran Covid-19. Besarnya jumlah penduduk, hubungan sistem kekerabatan yang kuat, dan terbatasnya sarana prasarana kesehatan, menyebabkan kekhawatiran pemerintah. Tingginya mobilitas penduduk dalam memenuhi kebutuhan ekonomi, adalah tantangan terbesar yang dihadapi pemerintah dalam usaha meminimalisasi dampak Covid-19. Meskipun pemerintah sebelum wabah ini meluas telah sukses menekan angka mobilitas dengan melarang melakukan berbagai aktivitas seperti raya idul fitri dan menghindari keramaian dengan menutup berbagai usaha, tempat peribadatan, namun hal tersebut berjalan sesaat. Kuatnya tekanan sosial dan ekonomi yang mendorong masyarakat melakukan mobilitas sebagai tantangan pemerintah untuk menyiapkan masyarakat hidup Bersama Covid-19. New Normal adalah sebuah langkah positif membangun kesadaran masyarakat peduli dengan Covid-19. Sebagaimana studi (Qazi et al., 2020), bahwa kesadaran untuk menjaga jarak, menggunakan alat pelindung diri dapat menurunkan jumlah kasus.

Kesadaran spasial merupakan sebuah model membangun kesadaran masyarakat dengan menggunakan informasi geospasial sebagai dasar masyarakat dalam mengambil keputusan dalam menggunakan alat pelindung diri (APD). Pentingnya membangun kesadaran melalui media perlu dipertimbangkan oleh pemerintah, karena media mampu membentuk persepsi masyarakat untuk bertindak lebih dalam mengurangi penyebaran (Karasneh et al., 2020). Kesadaran spasial adalah salah satu bentuk kesadaran yang dibangun berdasarkan persepsi keruangan dengan mengintegrasikan lokasi dan tempat kejadian.

Rasio kerentanan wilayah merupakan salah satu informasi geospasial yang bertujuan untuk memberikan informasi tentang rasio kerentanan penduduk pada pada suatu wilayah terhadap Covid-19. Rasio kerentanan wilayah yang dihitung atas dasar jumlah penduduk usia lanjut dengan jumlah penduduk saat ini, memberikan gambaran secara matematis masyarakat. 
Berdasarkan hasil analisis spasial, rasio kerentanan penduduk di Jawa Timur tertinggi kedua setelah DKI Jakarta. Sebagaimana penjelasan Gugus Tugas Percepatan Penanganan Covid-19 menyatakan bahwa Jawa Timur masuk dalam daftar rawan Covid-19, karena tingginya jumlah penduduk dan banyaknya usia lanjut yaitu $12,64 \%$.

Digunakannya usia sebagai dasar dalam menentukan rasio kerentanan terhadap Covid19, karena dari sebagian besar kasus kematian terjadi pada usia lanjut. Virus Corona dapat menjangkiti semua kelompok umur penduduk. Namun, setiap kelompok umur memiliki respon yang berbeda terhadap virus corona ini. Kelompok umur yang paling rentan terkena dampak penyebaran COVID-19 dan memiliki resiko kematian tertinggi adalah usia lanjut lansia (Dowd et al., 2020; Leung, 2020). Penduduk usia lanjut merupakan kelompok umur yang sudah mengalami penurunan sistem kekebalan tubuh sehingga rentan terserang penyakit seperti infeksi saluran pernafasan, diare dan pneumonia (Kemenkes RI, 2020). Hal tersebut dapat meningkatkan risiko infeksi virus corona dan menimbulkan gangguan yang cukup parah, bahkan menyebabkan kematian pada lansia.

Seiring bertambahnya usia seseorang, tubuh akan mengalami berbagai penurunan akibat proses penuaan. Mulai dari menurunnya produksi hormon, kekenyalan kulit, massa otot, kepadatan tulang, hingga kekuatan dan fungsi organ-organ tubuh. Kemudian, sistem imun sebagai pelindung tubuh pada lansia tidak dapat bekerja dengan maksimal layaknya saat masih muda. Akibatnya, sulit bagi orang lansia untuk melawan berbagai macam virus penyebab penyakit, termasuk virus corona COVID-19. Namun, di beberapa negara orang-orang berusia muda ada juga yang meninggal dunia akibat terinfeksi Covid-19. Meski kondisi mereka mungkin tidak terlalu parah seperti pada pasien orang dewasa, tetapi risiko anak-anak, terutama bayi, terinfeksi virus corona tetap tidak boleh disepelekan. Terlebih jika anak-anak tersebut sebelumnya mengidap pneumonia yang berisiko memperburuk infeksi Covid-19.

Gugus Tugas Percepatan Penanganan COVID-19 (2020) menyatakan upaya pemerintah dalam menangani Covid-19 diupayakan secara maksimal dengan melakukan berbagai cara pencegahan awal, salah satunya adalah dengan memberikan informasi dan memperhatikan para masyarakat di setiap daerah Indonesia. Bentuk awal seperti analisis kerentanan yang dilakukan sebagai upaya meningkat kesadaran masyarakat akan bahaya Covid-19. Pada prinsipnya analisis kerentanan digunakan sebagai: (1) alat diagnostic untuk memahami masalah dan faktor penyebab kerentanan, (2) alat perencanaan sebagai dasar penetapan prioritas kegiatan serta urutan kegiatan yang direncanakan, (3) alat pengukuran risiko untuk menilai risiko secara spesifik, dan (4) alat untuk pemberdayaan dan mobilisasi kelompok masyarakat yang rentan (Benson, 2007). Data analisis yang diperoleh dapat sebagai gambaran ke depan dalam pencegahan penyebaran dan dapat menjadi fokus utama dalam penangan Covid di setiap daerahnya.

Berdasarkan realitas dan permasalahan-permasalahan yang telah diuraikan di atas di mana mewabahnya Covid-19 pada masyarakat terutama daerah Indonesia menyebabkan kekhawatiran dan dibutuhkan penangan secara cepat dan tepat. oleh sebab itu dibutuhkan analisis kerentanan penduduk sebagai upaya awal untuk memfokuskan dan cepat tanggap akan penyebaran Covid-19 agar masyarakat juga tetap waspada dalam menjaga diri dalam aktivitas sosialnya. Maka penting dilakukan penelitian ini dengan judul "Analisis Kerentanan Penduduk terhadap COVID-19 Wilayah Malang Raya berdasarkan perspektif spasial". Berdasarkan permasalahan tersebut penelitian ini bertujuan untuk mengungkap apakah rasio kerentanan berdampak pada kesadaran masyarakat terhadap covid-19. 


\section{Metode}

Penelitian ini merupakan penelitian survey yang bertujuan untuk mendeskripsikan kerentanan Masyarakat Desa Pulungdowo terhadap Covid-19 dari perspektif spasial. Kerentanan masyarakat dianalisis berdasarkan komposisi penduduk usia lanjut dengan mempertimbangkan jenis kelamin. Penelitian ini menggunakan perspektif spasial sebagai dasar dalam analisis.

\subsection{Lokasi Penelitian}

Secara spesifik lokasi penelitian dilakukan di desa Pulungdowo Kecamatan Tumpang Kabupaten Malang. Adapun lokasi penelitian dipaparkan pada Gambar 1.

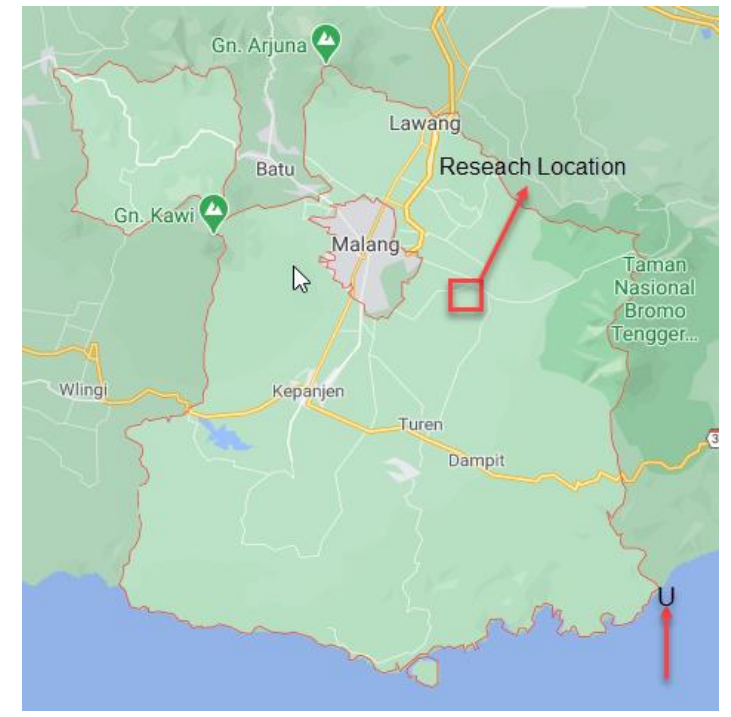

\section{Gambar 1. Peta Lokasi Penelitian}

\subsection{Pengumpulan Data}

Pengumpulan data dilakukan dengan menggunakan metode survey dan wawancara. Survey dilakukan dengan menggunakan aplikasi survey 123 dari ESRI. Untuk memperoleh data tingkat kesadaran masyarakat dalam menggunakan alat pelindung diri (APD) dari level desa hingga Kabupaten dan kota di Jawa Timur. Wawancara dilakukan untuk mendalami informasi terkait alasan menggunakan alat pelindung diri maupun tidak kaitannya dengan covid-19. Populasi pada penelitian ini meliputi semua masyarakat desa Pulungdowo sebanyak 2208 jiwa.

\subsection{Analisis Data}

Ruang lingkup analisis pada penelitian ini meliputi rasio kerentanan penduduk desa Pulungdowo berdasarkan jenis gender yang dikomparasikan dengan rasio kerentanan pada skala lokal, regional, dan nasional. Adapun analisis kerentanan dilakukan dengan menggunakan rasio kerentanan menurut Kementerian Dalam Negeri Republik Indonesia sebagaimana berikut.

Population Vulnerability Ratio $=\frac{\text { Total Population Age above } 60+}{\text { Total Population }}$ 
The levels of vulnerability are expressed in the following categories.

$$
\begin{array}{ll}
<0-0.1 & =\text { Low } \\
>0.1-0.2 & =\text { Moderate } \\
>0.2 & =\text { High }
\end{array}
$$

(Sumber: Gugus Penangan percepatan Covid-19)

Rasio kerentanan selanjutnya dibandingkan dengan tingkat kesadaran masyarakat dalam menggunakan alat pelindung diri APD khususnya masker. Keterbatasan penelitian ini terletak pada parameter rasio yang hanya menggunakan variabel usia lansia. Untuk perlu dipertimbangkan dengan variabel yang lain.

\section{Hasil dan Pembahasan}

\subsection{Rasio Kerentanan Penduduk Desa Pulungdowo}

Berdasarkan hasil analisis yang telah dilakukan terhadap 2208 jiwa penduduk desa Pulungdowo Kecamatan Tumpang, yang terdiri dari 1090 jiwa perempuan dan 1118 jiwa lakilaki dengan jumlah usia lanjut di atas 60 tahun sebanyak 414 jiwa dapat dikategorikan rasio kerentanan desa Pulungdowo dalam kategori sedang dengan skor 0.1875. Dari kategori tersebut menempat usia lanjut perempuan memiliki rasio kerentanan lebih tinggi dari pada laki-laki dengan skor 0.1963. Adapun hasil analisis dipaparkan sebagaimana Tabel 1.

Tabel 1. Rasio Kerentanan Penduduk Desa Pulungdowo Terhadap Covid-19

\begin{tabular}{llllll}
\hline No & Vulnerability & $\begin{array}{l}\text { Total } \\
\text { Population }\end{array}$ & $\begin{array}{l}\text { Total Elderly } \\
\text { Population }\end{array}$ & $\begin{array}{l}\text { Vulnerability } \\
\text { Ratio }\end{array}$ & Category \\
\hline 1. & Male & 1118 & 200 & 0.1788 & Moderate \\
2. & Female & 1090 & 214 & 0.1963 & Moderate \\
\hline & $\begin{array}{l}\text { Average } \\
\text { vulnerability }\end{array}$ & 2208 & 414 & 0.1875 & Moderate \\
\hline
\end{tabular}

Tabel 2. Rasio Kerentanan pada skala lokal, regional, dan Nasional

\begin{tabular}{clll}
\hline No & Scale Vulnerability & Vulnerability Ratio & Category \\
\hline 1. & Lokal (Malang-raya) & 0.13 & Moderate \\
2. & Regional (Jawa Timur) & 0.14 & Moderate \\
3. & Nasional & 0.05 & Low \\
\hline
\end{tabular}

Berdasarkan hasil analisis kerentanan terhadap covid-19, desa Pulungdowo memiliki tingkat kerentanan sedang. Tingkat tersebut memposisikan penduduk desa Pulungdowo memiliki kerentanan tinggi. Tingginya rasio tersebut disebabkan tingginya jumlah penduduk usia lanjut.

Kelompok penduduk berusia 60+ menjadi salah satu indikator atau dapat dikatakan yang paling rentan terkena Covid-19, karena banyak penelitian sebelumnya menyatakan bahwa bertambahnya usia juga diikuti dengan meningkatnya kecenderungan untuk sakit dan memiliki keterbatasan fisik karena terjadinya penurunan kemampuan fisik yang cukup drastis (Gatimu et 
al., 2016). Sedangkan menurut Pakar Geriatri UGM, Probosuseno (dalam kompas.com, 21 April 2020), faktor yang membuat lansia rentan tertular Covid-19 adalah karena lansia mengalami penurunan kapasitas fungsional hampir pada seluruh sistem tubuh termasuk imunitasnya. Ditambah dengan banyaknya lansia yang mempunyai penyakit bawaan seperti autoimun, diabetes, tekanan darah tinggi, kanker dan jantung. Dari berbagai fakta tersebut menunjukkan bahwa warga yang berusia lansia pada posisi yang rentan terinfeksi Covid-19 (Hakim, 2020).

Kerentanan Lansia dari segi kesehatan juga tercermin dari data statistik lansia yang meninggal karena Covid-19 di banyak negara. Di Malaysia, lansia yang meninggal karena Covid-19 sebanyak 62,6\% (english.astroawani.com, 16 April 2020); 85\% di Brazil, 95\% di Italia, 95,5\% di Spanyol (poder360.com, 4 April 2020); 80\% di Tiongkok (Newsdetik.com, 13 Mei 2020). Sementara di Indonesia, menurut informasi yang ada menunjukkan bahwa mayoritas korban meninggal akibat Covid-19 adalah yang berusia 60 ke atas (Wartaekonomi, 23 Maret 2020).

Tingkat kerentanan penduduk secara mendalam dibedakan atas jenis gender yaitu laki-laki dan lansia perempuan. Berfokus pada kategori tersebut, hasil analisis menunjukkan terdapat perbedaan tingkat kerentanan dalam perbedaan jenis kelamin terhadap kasus Covid-19. Penelitian sebelumnya menyebutkan bahwa laki laki memiliki tingkat kematian lebih tinggi, meskipun tingkat kerentanan lebih rendah dari pada wanita. Hal ini karena tingginya kandungan enzim pada darah laki-laki yang digunakan virus untuk menginfeksi sel, sehingga membantu virus bertahan di paruparu (Science Alert, 2020). Mengacu pada pernyataan tersebut, itu artinya penduduk usia lanjut laki-laki lebih rentan terpapar Covid-19 daripada penduduk usia lanjut perempuan. Mendalami data yang diperoleh untuk usia warga Desa Pulungdowo, jumlah usia lanjut laki-laki mencapai 200 orang, jumlah tersebut lebih rendah daripada jumlah usia lanjut perempuan yaitu 214 jiwa. Hasil yang telah dihitung untuk kerentanannya laki-laki $0.1788 \%$ dan perempuan $0.1963 \%$. Secara umum, laki-laki lebih beresiko terkena infeksi COVID-19 karena cenderung lebih sedikit menghabiskan waktu untuk masalah perawatan kesehatan sendiri, daripada wanita (Walter \& McGregor, 2020). Penelitian tentang kondisi pasien COVID-19 di Wuhan, Cina menghasilkan temuan, bahwa secara klinis pria lebih rentan terkena penyakit dan tingkat keparahan yang serius, dibandingkan dengan wanita (Jin et al., 2020).

Jika dibandingkan dengan rasio kerentanan pada skala lokal, regional, dan nasional kerentanan penduduk desa Pulungdowo masih di atas rata-rata. Tingginya angka kerentanan penduduk terhadap covid-19 bukan menjadi masalah di Pulungdowo, karena aktivitas masyarakat desa tidak sekompleks masyarakat yang tinggal di kota. Demikian halnya lingkungan desa lebih sehat jika dibandingkan dengan masyarakat kota. Dari hasil analisis rasio kerentanan tidak selalu berbanding lurus dengan kasus covid-19.

\subsection{Kerentanan Pada Skala Lokal}

Kajian pada skala lokal difokuskan pada wilayah Malang raya yang meliputi Kota Malang, Kota Batu dan Kabupaten Malang. Berdasarkan hasil analisis tingkat kerentanan wilayah Malang raya masuk dalam kategori sedang dengan nilai rentangan 0,12-0,14. Gambar 1 menunjukkan perbandingan hasil analisis kerentanan konsus covid-19 di Malang Raya. 


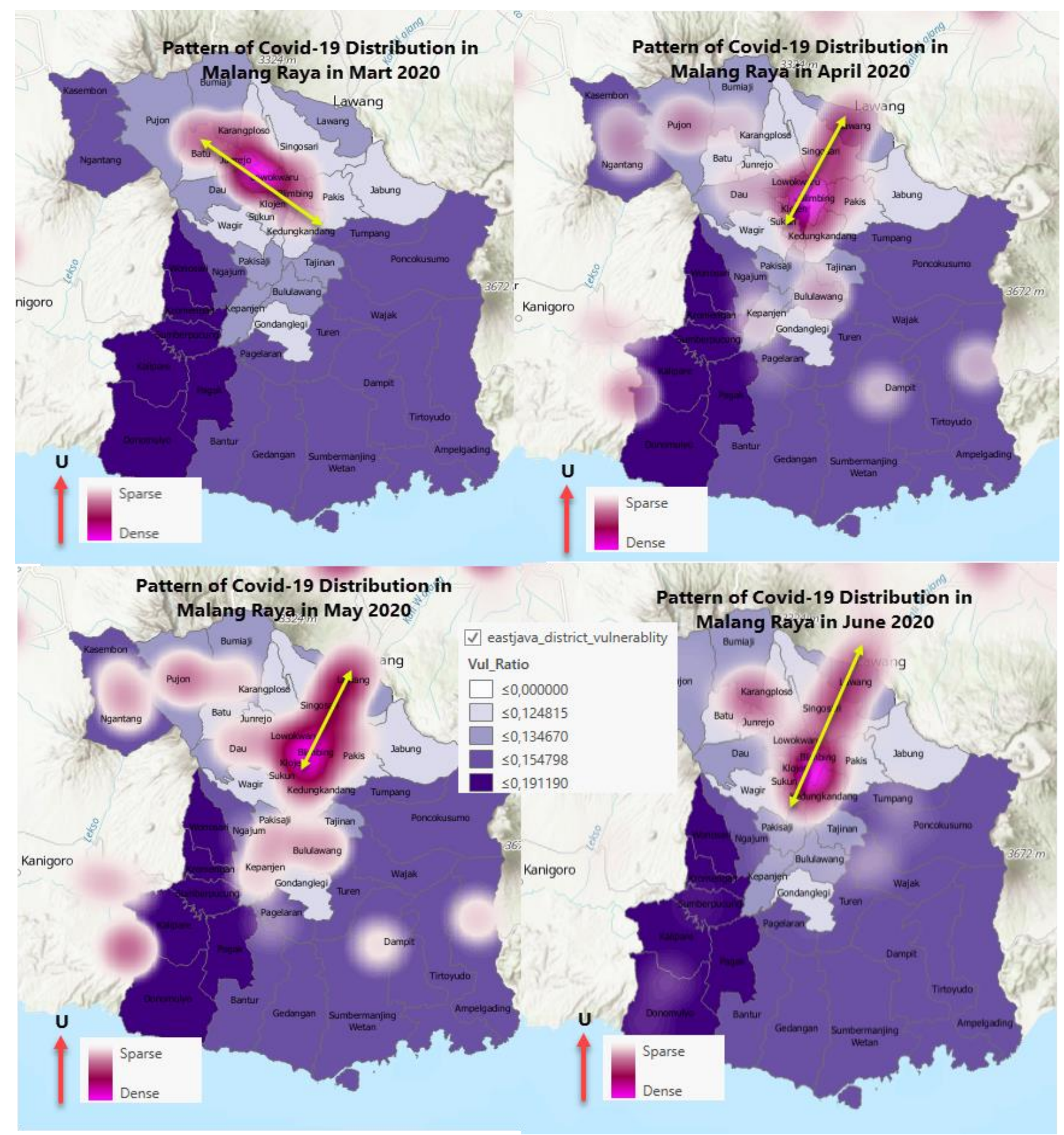

Gambar 1. Kerentanan penduduk pada skala lokal

(Sumber: hasil analisis)

Hasil analisis kerentanan penduduk pada skala lokal bahwa Malang Raya memiliki tingkat kerentanan sedang. Namun demikian nilai kerentanan tersebut tidak selalu mengindikasikan tingginya kejadian kasus positif di daerah tersebut. Namun tingginya kasus positif di perkotaan lebih disebabkan oleh faktor mobilitas yang tinggi, kelelahan, dan kesadaran masyarakat.

Tingginya angka kematian laki-laki jika dibanding dengan perempuan, hal ini menunjukkan bahwa laki-laki memiliki tingkat kesadaran lebih rendah jika dibanding dengan perempuan. Sebagaimana hasil survey keruangan untuk mengetahui tingkat kesadaran masyarakat dalam menggunakan alat pelindung diri (APD) ditemukan bahwa laki-laki memiliki tingkat kesadaran 
yang rendah. Demikian halnya laki-laki memiliki mobilitas yang tinggi dengan dengan rata-rata lama kerja di luar 5-8 Jam/hari.

\subsection{Kerentanan Penduduk Pada Skala Regional}

Pada skala regional kajian difokuskan pada provinsi Jawa Timur yang notabennya provinsi tempat penelitian dilakukan. Ditinjau dari kasus kejadian kasus Covid-19 Jawa Timur merupakan provinsi kedua dengan tingkat kasus positif tertinggi kedua setelah Jakarta. Berdasarkan hasil analisis tingkat kerentanan per Kabupaten dan Kota.
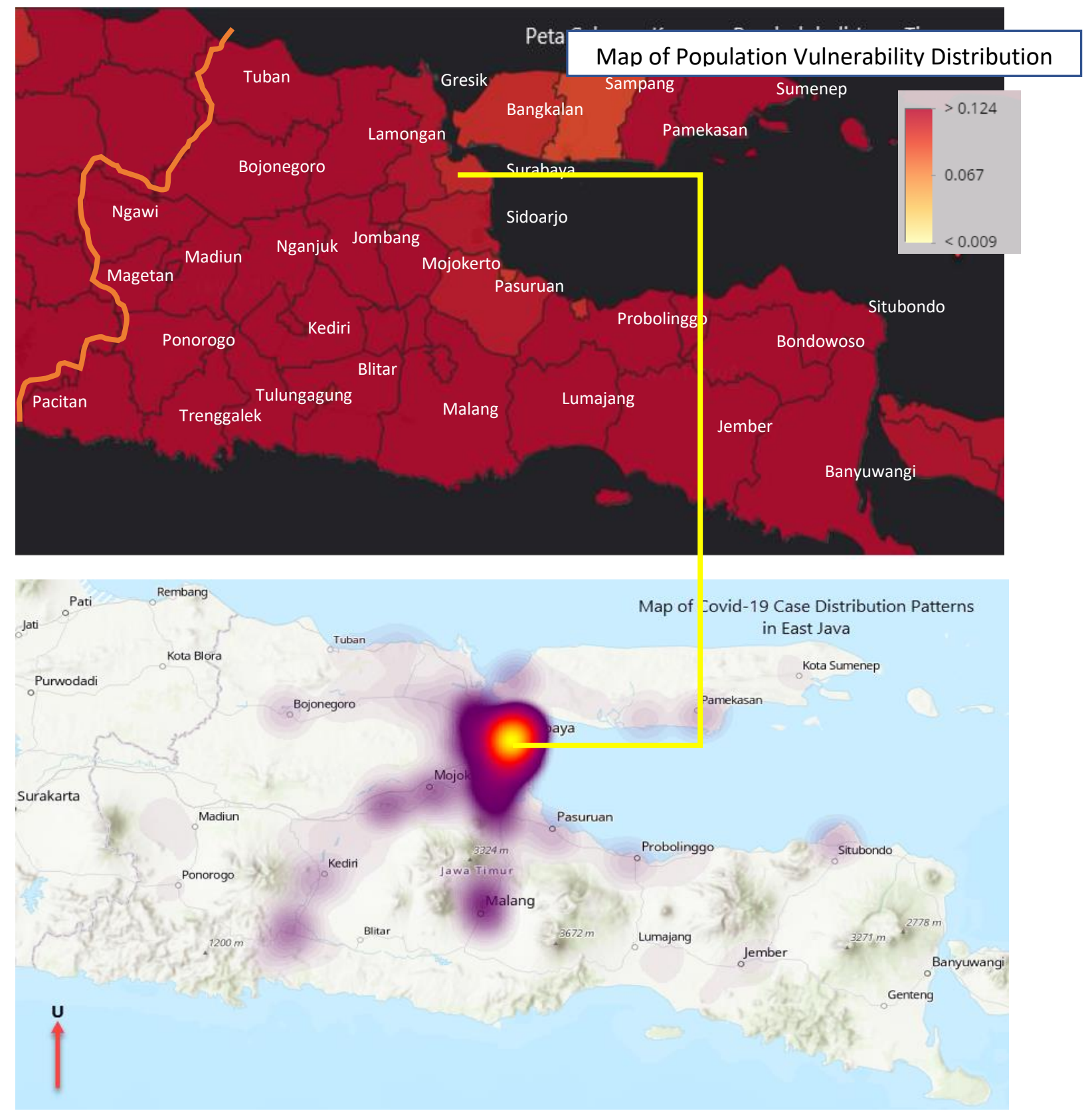

Gambar 2. Map of Population Vulnerability Distribution in East Java (https://bnpb-inacovid19.hub.arcgis.com) 
Berdasarkan peta distribusi kerentanan penduduk terhadap Covid-19 di Jawa Timur menunjukkan $80 \%$ wilayah di Jawa Timur pada tingkat kerentanan sedang. Kondisi ini mengindikasikan bahwa secara provinsi Jawa Timur rentan terhadap penyebaran Covid-19. Kondisi ini cukup terbukti, namun tidak semua wilayah dalam kategori kerentanan tinggi memiliki jumlah kasus positif Covid juga tinggi. Sebagaimana contoh Kota Surabaya dalam hasil analisis menunjukkan pada kategori rendah, namun fakta di lapangan menunjukkan perkembangan kasus yang cukup tinggi. Hal tersebut dapat dilihat pada peta sebaran Covid-19 di Jawa Timur (Gambar 2).

\subsection{Kerentanan Penduduk Pada Skala Nasional}

Kerentanan penduduk terhadap Covid-19 pada skala Nasional dipaparkan sebagaimana mana peta pada Gambar 3.

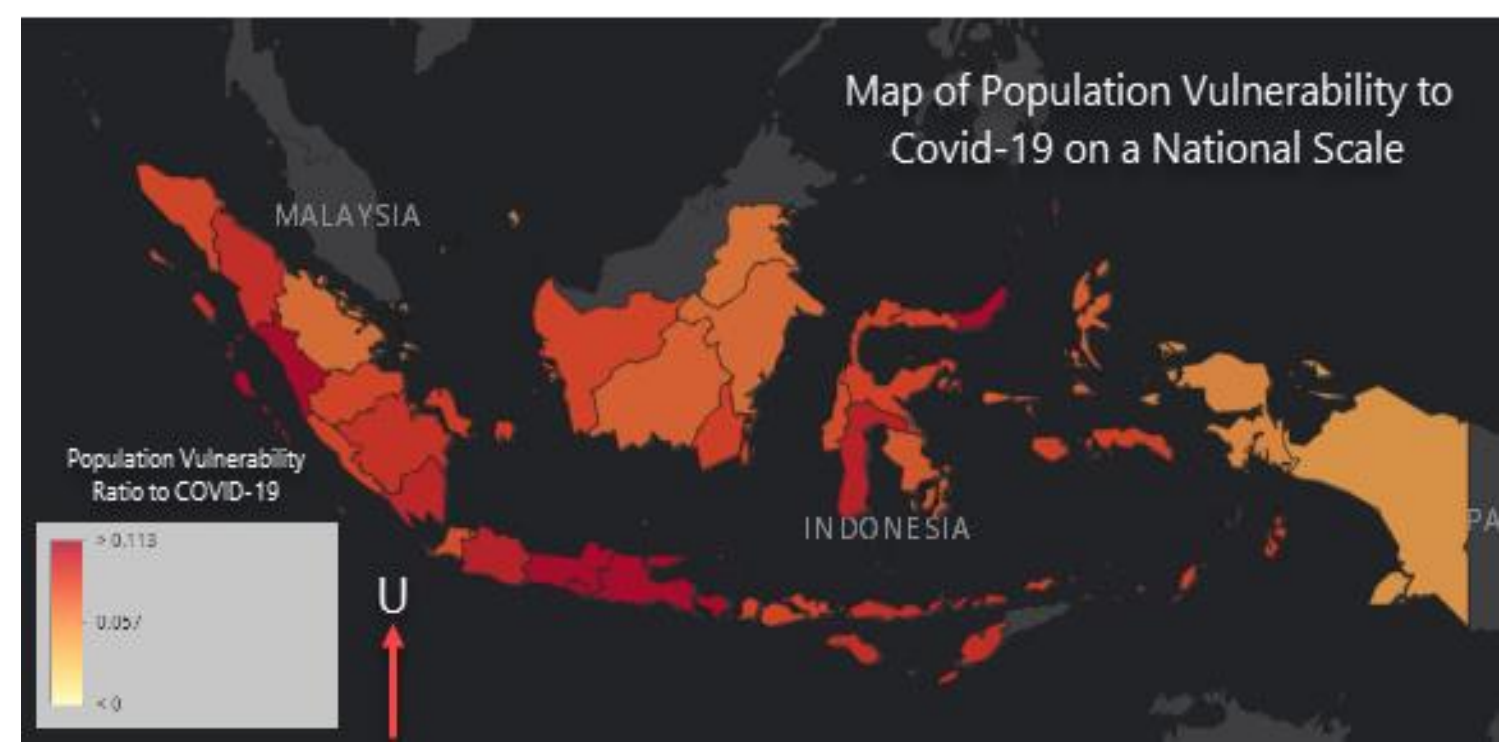

Gambar 3. Map Distribution of Population Vulnerability to Covid-19 on a National Scale (https://bnpb-inacovid19.hub.arcgis.com).

Berdasarkan hasil analisis kerentanan pada peta tersebut, kerentanan tertinggi terdapat di provinsi Jawa Timur, Jawa Tengah, Yogyakarta, Padang dan Maluku Utara. Namun demikian kerentanan tersebut tidak selalu berbanding lurus dengan jumlah kasus Covid-19. Artinya Kerentanan tinggi tidak selalu menunjukkan banyaknya kasus di daerah provinsi tersebut. Tingginya tingkat kerentanan pada skala nasional sebesar 0,113 di mana jika diklasifikasikan termasuk pada tingkat kerentanan sedang. Tingginya tingkat kerentanan menunjukkan provinsi tersebut memiliki penduduk usia lanjut yang banyak. Dari hasil analisis di atas Provinsi Jawa Timur masuk dalam kategori tingkat kerentanan tinggi dengan dengan nilai 0,14 meskipun dalam kategori sedang, hal ini patut diwaspadai tingginya angka kerentanan tersebut.

\section{Simpulan}

Pandemi Covid-19 yang mewabah ke seluruh daerah menyebabkan kekhawatiran dan meningkatnya resiko kesehatan dari masyarakat di Indonesia. Meningkatnya jumlah kasus di setiap daerahnya menyebabkan semakin tinggi resiko terjangkit Covid-19 pada masyarakat. Resiko terjangkit Covid-19 pada masyarakat sebenarnya dapat terjangkit pada setiap 
kelompok masyarakat, namun resiko tersebut lebih rentan terkena terhadap kelompok masyarakat lanjut usia (Lansia). Hal tersebut dikarenakan pada kelompok lanjut usia memiliki tingkat imunitas yang rendah. Selain hal tersebut jumlah penduduk juga menjadi indikator penting dalam penyebaran dan tingginya resiko terkena Covid-19 di suatu daerah. Desa Pulungdowo menjadi salah satu daerah yang memiliki tingkat kerentanan penduduk yang hampir menyentuh tingkat tinggi untuk kerentanannya. Tingginya tingkat kerentanan penduduk dikarenakan jumlah penduduk disertai mobilitas dan juga jumlah kelompok lansia di desa pulungdowo dengan tingkat kerentanan mencapai $0.1875 \%$ dengan kategori sedang. Rasio tingkat kerentanan penduduk Desa Pulungdowo juga memiliki perbedaan berdasarkan jenis kelaminnya, dimana rasio tingkat kerentanan laki-laki mencapai 0.1788 dan untuk perempuan mencapai $0.1963 \%$. Berdasarkan hasil tersebut kerentanan penduduk Desa Pulungdowo berdasarkan jenis kelamin, kerentanannya lebih tinggi penduduk perempuan daripada laki-laki.

\section{Ucapan Terima Kasih (Opsional)}

The author's gratitude to the State University of Malang for providing research grants for the PNPB cluster of the Center for Disaster, Mitigation, and Environment - LP2M UM so that the author has the opportunity to present some of the research results. In addition, researchers also expressed their gratitude to ESRI Indonesia for granting a Grand License so that it can facilitate the implementation of field surveys.

\section{Daftar Rujukan}

Bhattacharya, S., Basu, P., \& Poddar, S. (2020). Changing epidemiology of SARS-CoV in the context of COVID-19 pandemic. Journal of Preventive Medicine and Hygiene, 61(2), E130-E136. https://doi.org/10.15167/2421-4248/jpmh2020.61.2.1541

Contini, C., Di Nuzzo, M., Barp, N., Bonazza, A., De Giorgio, R., Tognon, M., \& Rubino, S. (2020). The novel zoonotic COVID-19 pandemic: An expected global health concern. The Journal of Infection in Developing Countries, 14(03), 254-264.

Dowd, J. B., Andriano, L., Brazel, D. M., Rotondi, V., Block, P., Ding, X., Liu, Y., \& Mills, M. C. (2020). Demographic science aids in understanding the spread and fatality rates of COVID-19. Proceedings of the National Academy of Sciences of the United States of America, 117(18), 9696-9698. https://doi.org/10.1073/pnas.2004911117

Gatimu, S. M., Milimo, B. W., \& Sebastian, M. S. (2016). Prevalence and determinants of diabetes among older adults in Ghana. BMC Public Health, 16(1), 1-12. https://doi.org/10.1186/s12889-016-3845-8

Hakim, L. N. (2020). Perlindungan Lanjut Usia Pada Masa Pandemik Covid-19. Info Singkat, XII (10/II/Puslit/Mei/2020).

Jin, J. M., Bai, P., He, W., Wu, F., Liu, X. F., Han, D. M., Liu, S., \& Yang, J. K. (2020). Gender Differences in Patients With COVID-19: Focus on Severity and Mortality. Frontiers in Public Health, 8(April), 1-6. https://doi.org/10.3389/fpubh.2020.00152

Karasneh, R., Al-Azzam, S., Muflih, S., Soudah, O., Hawamdeh, S., \& Khader, Y. (2020). Media's effect on shaping knowledge, awareness risk perceptions and communication practices of pandemic COVID-19 among pharmacists. Research in Social and Administrative Pharmacy, April. https://doi.org/10.1016/j.sapharm.2020.04.027

Kemenkes RI. (2020). Hindari Lansia Dari Covid 19.

Lau, H., Khosrawipour, V., Kocbach, P., Mikolajczyk, A., Schubert, J., Bania, J., \& Khosrawipour, T. (2020). The positive impact of lockdown in Wuhan on containing the COVID-19 outbreak in China. Journal of Travel Medicine, 27(3). https://doi.org/10.1093/jtm/taaa037

Leung, C. (2020). Risk factors for predicting mortality in elderly patients with COVID-19: A review of clinical data in China. Mechanisms of Ageing and Development, 188(April), 111255. https://doi.org/10.1016/j.mad.2020.111255 
Jurnal Integrasi dan Harmoni Inovatif Ilmu-IImu Sosial, 1(4), 2021, 477-487

Majumdar, P., Biswas, A., \& Sahu, S. (2020). COVID-19 pandemic and lockdown: cause of sleep disruption, depression, somatic pain, and increased screen exposure of office workers and students of India. Chronobiology International, 37(5), 1-10. https://doi.org/10.1080/07420528.2020.1786107

Qazi, A., Qazi, J., Naseer, K., Zeeshan, M., Hardaker, G., Maitama, J. Z., \& Haruna, K. (2020). Analyzing situational awareness through public opinion to predict adoption of social distancing amid pandemic COVID-19. Journal of Medical Virology, 92(7), 849-855. https://doi.org/10.1002/jmv.25840

Shammi, M., Bodrud-Doza, M., Islam, A. R. M. T., \& Rahman, M. M. (2020). Strategic assessment of COVID-19 pandemic in Bangladesh: comparative lockdown scenario analysis, public perception, and management for sustainability. Environment, Development and Sustainability, 22(October 2020), 1-44. https://doi.org/10.1007/s10668-020-00867-y

Shereen, M. A., Khan, S., Kazmi, A., Bashir, N., \& Siddique, R. (2020). COVID-19 infection: Origin, transmission, and characteristics of human coronaviruses. Journal of Advanced Research, 24(March), 91-98. https://doi.org/10.1016/j.jare.2020.03.005

Thornton, J. (2020). Covid-19: A\&E visits in England fall by 25\% in week after lockdown. BMJ (Clinical Research Ed.), 369(April), m1401. https://doi.org/10.1136/bmj.m1401

Walter, L. A., \& McGregor, A. J. (2020). Sex- And gender-specific observations and implications for COVID-19. Western Journal of Emergency Medicine, 21(3), 507-509. https://doi.org/10.5811/westjem.2020.4.47536

WHO. (2020). Coronavirus Disease 2019. In Coronavirus disease 2019 (COVID-19) Situation Report - 41 (Vol. 14, Issue 6). https://doi.org/10.1213/xaa.0000000000001218

Yuliana, Y. (2020). Corona virus diseases (Covid-19): Sebuah tinjauan literatur. Wellness And Healthy Magazine, 2(1), 187-192. 